\title{
A Pragmatic Study of CNN and BBC News Headlines Covering the Syrian Conflict
}

\author{
Fareed Hameed Al-Hindawi ${ }^{1}$, Abid Hmood $\mathrm{Ali}^{2 *}$ \\ ${ }^{1}$ Department of English, College of Education for Human Sciences, University of Babylon, Iraq \\ ${ }^{2}$ Department of English, College of Education for Human Sciences, University of TIKRIT, Iraq
}

Corresponding Author: Abid Hmood Ali, E-mail: abhali2012@yahoo.com

\section{ARTICLE INFO}

Article history

Received: January 23, 2018

Accepted: March 26, 2018

Published: June 30, 2018

Volume: 9 Issue: 3

Advance access: May 2018

Conflicts of interest: None

Funding: None

\author{
Key words: \\ Pragmatics, \\ Pragmatic Analysis, \\ Speech Acts, \\ News Headlines, \\ Media, \\ BBC News Channel, \\ CNN News Channel
}

\begin{abstract}
Lately, there has been a growing interest in media. As a result, many trends are found from both the academic and industrial points of view. News channels, for example, play an important role in transmitting news about political situations, military events and other issues to people all over the world. The language used in news reports or even in their headlines is very influential in attaining the communicative intent of such news reports. This language is characterized by various linguistic features. One aspect of those features is the pragmatic one. This latter issue has not been given its due attention in research study. Precisely, the use of speech acts as a basic component of pragmatics has not been sufficiently tackled in research work in this regard. Thus, the present study attempts to fill this gap and investigate the types of speech acts employed in $\mathrm{CNN}$ and BBC headlines that represent the Syrian conflict. Fifty-six headlines are selected from each of these news channels - 26 from CNN and 30 from BBC. This study purports that headlines can be loaded with the encoded pragmatic meanings which makes this study worth conducting to reveal those kinds of meanings. The selected period ranges from September 2015 to May 2016. The investigation performed by this study shows that scrutinizing the speech acts employed in the headlines in news channels can be a good way to understand the intended meaning set by writers. It is found out that assertive speech acts are the most frequent speech acts used in the headlines of $\mathrm{CNN}$ and $\mathrm{BBC}$ news channels. The results also indicate that the headlines of CNN news channel show a preponderance use of commissives whereas the headlines of BBC news channel show an eminent employment of expressives.
\end{abstract}

\section{INTRODUCTION}

Mass media has considerably influenced our life. TV channels and newspapers play an essential role in this regard through news reports. In these reports, headlines are constructed and manipulated in order to achieve certain purposes. The choice of language is a prerequisite to ensure the intended influence by directing readers' attention to certain issues. Editors reflect their opinions and attitudes about the issues conveyed by the news. A linguistic analysis of the way these pieces of news are transmitted may reveal a lot about these opinions and attitudes. In this vein, a pragmatic analysis of the headlines may represent an effective means for showing the role of headlines in initiating and sustaining the meanings intended. According to Chiluwa (2007: 70), pragmatic analysis plays a key role in the headlines because the pragmatic meanings are based on the writer's intentions. Language is a means of communication and presenting beliefs, but what is important is to know the way it is used to shape ideas (Beard, 2000:18).

The role of pragmatics can emerge in revealing the real intentions of text-producer that are sometimes obscured, and thus, lead to a sense of misunderstanding on the part of the text- producer (Van Dijk, 1977:216). Pragmatics is viewed as an act of communication which affects all fields of life. Mey (2001:6) puts it in this way "Pragmatics as the study of the way human being use their language in communication, bases itself on a study of those premises and determine how they effect and effectualize human language use."

It is well- known that the use of speech acts is part of the activities of human communication. Identifying the type of speech acts used can help the listener or reader infer something that is not expressed by the speaker explicitly.

Most previous studies of the language of headlines concentrate on the stylistic and rhetorical aspects of those that are employed in newspapers only such as: Muhammed's (2005) A Pragmatic Analysis of selected English Political Newspaper Headlines, Siposova's (2011) Headlines and Subheadlines: Tense, Modality and Register Based on Discourse Analysis of The British Tobloid The Sun, Abba and Nasiru's (2015) Speech Act Analysis of Daily Trust and The Nation Newspapers Headline Reports on "Boko Haram" Attacks, Prakash and Dhawan's (2017) Linguistic Divergences in Newspaper Headlines and Roya's (2017) The Rhetoric of Persian News Headlines: A Case Study of Euronews. There is only one study that tackles the headlines of news chan- 
nels which is Rustam's (2013) Pragmatic Analysis of CNN Headlines Representing Pakistan. It has been conducted to identify the illocutionary acts included in CNN news channel headlines representing Pakistan. However, there still a need for further research with regard to the headlines in TV news channels. To conduct such a kind of study, the current work sets itself to the task of investigating the speech acts in the language employed in news channels covering the Syrian conflict since it is believed here that it has not been given its due attention. In so doing, this study will attempt to fill this gap. The investigation of the language used in these headlines is intended to be carried out within the framework of the speech act theory. The model adopted in the study is Searle's (1979[1975]) speech acts.

The questions that are intended to be answered by this work can be formulated as follows:

1. Which speech acts are employed in the CNN headlines covering the Syrian conflict?

2. Which speech acts are employed in the BBC headlines covering the Syrian conflict?

3. Which speech acts are predominant in the headlines of $\mathrm{CNN}$ and BBC news channels?

4. As pragmatic strategies, how are explicit and implicit speech acts employed in the headlines of CNN and BBC news channels?

In association with aiming to find answers to the questions above, it is hypothesized that:

1) Assertives are most widely used in the headlines of $\mathrm{CNN}$ and $\mathrm{BBC}$ news channels.

2) Directives and declarations are very rare in the headlines of $\mathrm{CNN}$ and $\mathrm{BBC}$ news channels.

3) Explicit speech acts are used more than implicit speech acts in the headlines of $\mathrm{CNN}$ and BBC news channels.

4) Speech act theory provides an effective apparatus for analyzing headlines language in news channels.

The model adopted in this study is Searle's (1979[1975]) speech act theory. The pragmatic analysis is supported by a statistical analysis to quantitatively verify or refute the hypotheses of the study. This work limits itself to the analysis of the linguistic form and meaning that can be found in the headlines covering the Syrian conflict from September 2015-May 2016.

It is hoped that the findings of this study will be useful for news headline writers, editors and pragmatists.

\section{NEWS HEADLINES}

News is a word that is relatively difficult to define and there has never been a satisfactory definition (Rapeepat Cited in Duanprakhon 2012:8). For Reah (1998:4), news is information about recent events" that are of interest to a sufficiently large group or that may affect the lives of sufficiently large group."

As for headline, Reah (2002:13) states that it is a "unique type of a text that consists of a range of functions that specifically dictate its shape, content and structure." It is difficult to give a determinative and unambiguous definition of the term' headline' and it seems to be used intuitively, even in linguistic studies(Mardh,1980:14). Bell (1991:150) believes that headline is "an abstract of an abstract" in that it frames the story in a higher level. Headlines play a significant role in news transmitting. Taiwo (2007:244), for example, stresses the importance of headlines by saying that they are used to" initiate, sustain and shape discourse on the views of readers".

The language of headlines differs from everyday language. This difference is obvious in the fact that stories are written in the past tense headlines in the present tense (Tuchman,1978:106).

The importance of headlines in media discourse is reflected by Bell (1991:189) who states that the most important part is the kind of language used, how headline writer or editor uses language in such a way to stir up the reader's attention and what speech acts they can use to convey their message.

In the same vein, Ungerel (2000:48) stresses that a headline describes the essence of a news story in a few words. It gives information quickly and accurately and arouses the reader's curiosity. Dor (2003:720) moves further by claiming that, in addition to the semantic and pragmatic functions, it is "a communicative device whose function is to produce the optimal level of affinity between the content of the story and the reader's context of interpretation." The production of news is influenced by the main goal of media organization. In this regard, Fowler (1991:12) emphasizes that it is "a systematic sorting and selecting of events and topics according to a socially constructed set of categories." Stressing the role of discursive strategies in enhancing newsworthiness of the reported events, Bednarek and Caple (2012:44) add that "Newsworthiness is not inherent in events but established through language and image."

Headlines have different functions. Bell (1991:189), for example, distinguishes between headlines which " abstract the main event of the story" and "headlines which focus on a secondary event or a detail." Crystal and Davy (1969:146) refer to the complicated nature of headlines function as they say "Headlines have to contain a clear, succinct and if possible intriguing message, to kindle a spark of interest in the potential reader... whose eye moves swiftly down a page and stops when something catches his attention." Headlines perform three functions. They are used to provide a summary of the news, attract attention, and to provide an initial indicator of news value (Conboy,2007:13).

\section{ANALYTICAL FRAMEWORK OF THE STUDY}

Searle (1969:16) suggests that speech act is the minimal unit of communication. However, this unit falls under different types of macroclasses which in turn are sub-divided into microclasses.Searle (1979[1975]: 12-20) presents a taxonomy of these macro-classes of speech acts as follows:

1. Assertives: these acts commit the speaker to something being the case or to the truth of the expressed proposition. Like conclude, complain, etc. The direction of fit is that words match the world.

2. Directives: these acts are attempts by the speaker to get the hearer do something, for example: order, request, command, etc. In this class, the words cause the world to change.

3. Commissives: these acts commit the speaker to some future course of action, for example: promise, and com- 
mitment. This category involves changing the world according to the words.

4. Expressives: these acts empress a psychological state about a state of affairs expressed in the propositional content, for example, welcome, condole, apologise, etc. This class reflects a neutral direction of fit. In other words, there is no fit between words and the world.

5. Declarations: they bring about alternation in the status or condition of the referred object, e.g appoint, declare, etc. The direction of fit in this class is similar to that of directives.

This taxonomy which is schematized in Figure (1) will be the pragmatic apparatus of analysis.

Although this model of analysis is of three levels, only the first level will be basically appealed to. Micro-classes of speech acts will be made use as an indicator for macro-classes of speech acts. The third level of the model includes how the strategies employed are realized in the form of explicit or implicit speech acts. This kind of taxonomy will be adopted as the pragmatic analytical framework of the data under study.

\section{RESEARCH METHODOLOGY}

\section{Methods of Analysis}

The analysis of the data under scrutiny is of two types: qualitative (pragmatic) and quantitative (statistical). The former is done by means of the analytical framework discussed above. It aims at revealing what kind of speech acts are exploited in the news headlines. The latter is intended to statistically support the findings of the former analysis. It is done by means of the percentage equation.

\section{Data Collection}

The data are collected from online news sources which include CNN website (www.cnn.com) and BBC website (www.bbc.com). After copying the data from web pages, the data which are unnecessary are neglected. Then, the selected data are sampled. Out of that data, 26 and 30 headlines are selected from $\mathrm{CNN}$ and $\mathrm{BBC}$ news channels headlines respectively.

\section{RESULTS AND DISCUSSION}

The pragmatic analysis by means of the model of the study in addition to the statistical one are introduced in Table (1) below. This table shows the types of macro- speech acts employed in the CNN data in addition to the percentage of the frequency of their appearance in the data.

As illustrated in Table (1), the findings of analysis indicate that assertive speech acts have the highest percentage of the speech acts employed. According to Searle (1979[1975]), in assetives, the speaker is committed to something being the case. The vast majority of assertives used in the headlines on CNN news channel are either verbless (Headlines 3,9, 26: Appendix A) or with verbs (Headlines 1,6,7,8,12 13,14, $15,18,20,21,22,23,25,26)$.Moreover, all of the headlines used have the illocutionary force of 'informing' the reader

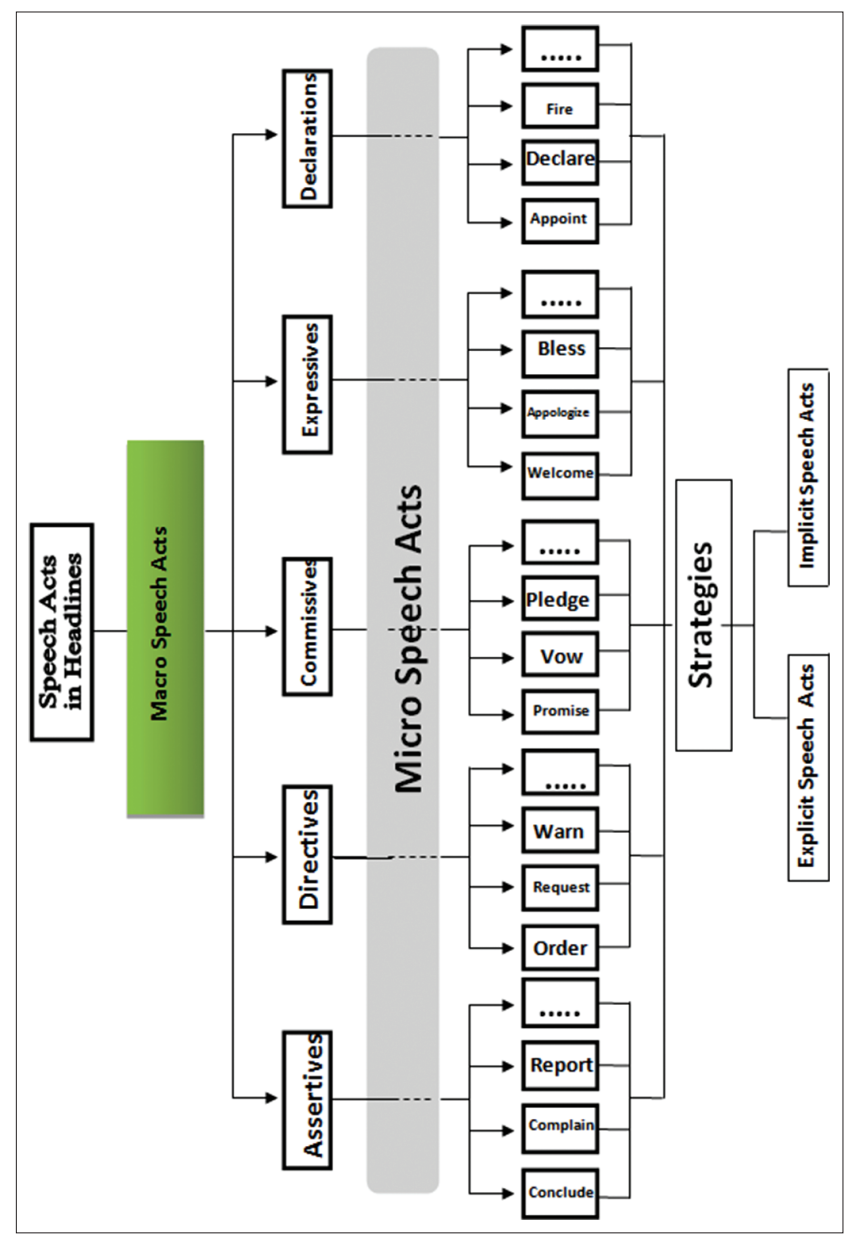

Figure 1. The Pragmatic Analytical Framework

Table 1. Types of speech acts and their percentages of use in headlines on CNN news channel

\begin{tabular}{lcc}
\hline Speech act type & Frequency & Percentage \\
\hline Assertives & 18 & 69.23 \\
Directives & 1 & 3.84 \\
Commissives & 4 & 15.38 \\
Expressives & 2 & 7.69 \\
Declarations & 1 & 3.84 \\
Total & 26 & 100 \\
\hline
\end{tabular}

about events happening or 'exposing' some facts in the news headlines. So, according to the procedure adopted, these acts will be considered to mean 'expose' or 'report' which lie in the second level of the model of analysis and are directly related to the first level i.e, assertives. The assertive speech acts outnumber other speech acts and are identified with a frequency of appearance that amounts to 18 and a percentage of $69.23 \%$. This can be attributed to the fact that the main function of headlines is to report or expose current states of affairs. Assertives tackle different topics in the headlines. It seems that the most common topics dealt with in this category are about the Syrian refugees and ISIS. Directives are used to get the reader do something whereas declarations are used to perform certain actions by certain people. However, a directive speech act (Headline 2) employs 'should 
stay' which refers to obligation and a declaration speech act (Headline 16) which employs the verb ' announce ' are employed one time for each with the percentage of $3.84 \%$.This may be due to the idea that headlines editors are not in a position to direct others through orders or to issue commands. In commissives, the speaker is committed to fulfill some future action or refrain from doing any one. They (Headlines $5,10,17,19)$ are identified with a frequency of appearance that amounts to 4 and a percentage of $15.38 \%$. In all these acts a performative verb which refers a sort of commitment is employed, i.e., they are explicit speech acts. These acts are mostly assigned to show the commitment of some political leaders or entities to certain future actions which are in behalf of the Syrian people. Expressives are used to express the feelings associated with a certain act. They (Headlines $4,24)$ are singled out with 2 frequencies and a percentage of $7.69 \%$. Both of them represent implicit speech acts which mean 'regret' and 'appreciate' respectively in the second level that are related to expressives in the first level. This low exploitation of expressives may indicate that the headlines give little attention to feelings and imply a seemingly neutral attitude to events.

Figure (2) provides a picture of the distribution of the speech acts employed in CNN news channel.

As for the analysis of the types of speech acts and their frequency of use in headlines on BBC news channel, they are introduced in table (2) below.

As revealed by Table (2), assertive speech acts have the highest percentage of the speech acts with a frequency of appearance that amounts to 21 and a percentage of $70 \%$. This is because these acts are used to indicate the current state of affairs. Regarding this category, the speech acts found in the second level of the model of analysis have the illocutionary force of 'reporting" or 'exposing' facts that are related to the news headlines which directly belong to the category of asssertives in the first level. The vast majority of the headlines use verbs as illocutionary force device (Headlines 2,3,6,7,8, 10, 12, 14,15,18,19,23,25,26,30: Appendix B) whereas headlines $(9,13,16,17,27)$ are verbless. The most common topics dealt with in this category are about Madaya, the Syrian refugees and the Syrian crisis in general. The employment of directives is characterized by the fact they are issued one time by MPs(Headline 20) with a percentage of 3.33\%. This speech act is performed by using 'should take' which is related to directive speech acts in the first level of the analysis. This employment may be construed in that headlines reporter in this channel wants to focus on the MPs of United Kingdom. Commissive speech acts(Headlines 1 and 22) are identified with a frequency of appearance that amounts to 18 and a percentage of $6.66 \%$.In these two speech acts, performative verbs are used in the second level that is related to commissives in the first level of the analysis. One is used by Trump as in the verb 'would send' while the other is an implicit speech act which is used to show the UK government's pledge to settle the Syrian refugees. The second highest rate of exploiting speech acts is represented by the use of expressives. There are 6 expressive speech acts (Headlines $4,5,11,21,24,29$ ) with a percentage of $20 \%$. Only headline (11) is an explicit speech act while the rest are implicit. Most of the propositions covered by way of expressive speech acts in the headlines are related to the suffering of the Syrian people. This indicates that BBC news channel show more sympathetic attitude towards the Syrian people than that is adopted by CNN headlines. Declarations are not used

Table 2. Types of speech acts and their percentages of use in headlines on BBC news channel

\begin{tabular}{lcc}
\hline Speech act type & Frequency & Percentage \\
\hline Assertives & 21 & 70 \\
Directives & 1 & 3.33 \\
Commissives & 2 & 6.66 \\
Expressives & 6 & 20 \\
Declarations & 0 & 0 \\
Total & 30 & 100 \\
\hline
\end{tabular}

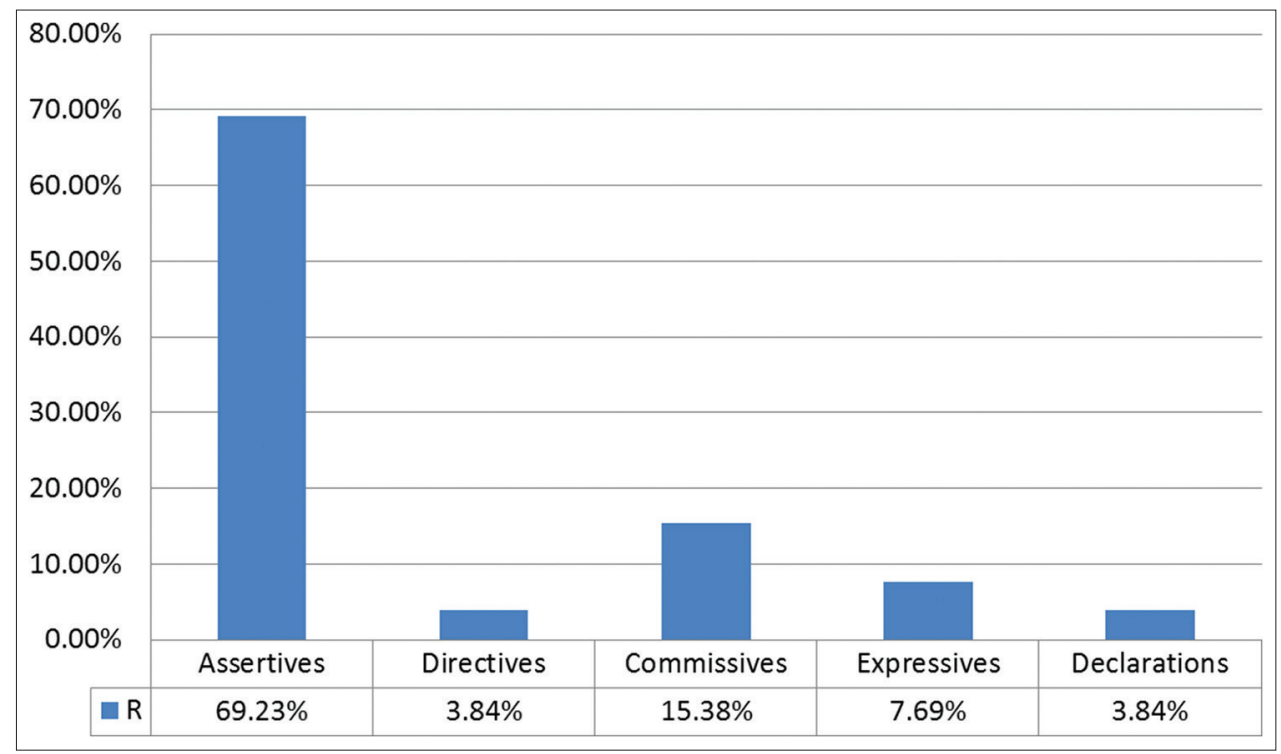

Figure 2. Percentages of the Speech Acts Used in Headlines on CNN News Channel 
in the headlines of $\mathrm{BBC}$ news channel because the context is not that of declaring certain actions by certain people rather than stating things. Figure (3) indicates the distribution of the speech acts used in BBC news channel.

In order to give a better picture of the speech acts employed in $\mathrm{CNN}$ and $\mathrm{BBC}$ news channels, their cumulative number is shown in Table (3) below.

Table (3) above presents a breakdown of the types of the speech acts employed and their distribution. Throughout the headlines of the two news channels, most of the speech acts types suggested by Searle (1979[1975]) are found in a variety of recurrence rates. Among the speech acts employed in the headlines of $\mathrm{CNN}$ and $\mathrm{BBC}$, the highest percentage is that of assertives.

As the same table shows, assertives are the most frequent speech acts employed in the headlines of CNN and BBC with frequencies of use that amounts to 18 and 21 and percentages of $69.23 \%$ and $70 \%$ respectively. There is only one directive speech act used in both $\mathrm{CNN}$ and BBC headlines with percentages of $3.84 \%$ and $3.33 \%$ respectively. Commissives are more commonly used with a frequency of appearance that amounts to 4 and a percentage of $15.38 \%$ in the headlines of $\mathrm{CNN}$ whereas they are used with a frequency of 2 and a percentage of $6.66 \%$ in BBC headlines. This may indicate that $\mathrm{CNN}$ news channel focuses on future events more than BBC news channel. Expressives are identified in $\mathrm{CNN}$ with a frequency of appearance that amounts to 2 and a percentage of $7.69 \%$ whereas they are identified in BBC with a frequency of 6 and a percentage of $20 \%$. The abundant use of expressives in BBC headlines may reveal that headlines reports are more sympathetic with the Syrians. In the headlines of $\mathrm{CNN}$, there is only one declaration speech act identified with a percentage of $3.84 \%$ whereas none is employed in those of the BBC. Figure (4) manifests the distribution of the speech acts employed in $\mathrm{CNN}$ and $\mathrm{BBC}$ news channels.

As for the analysis of the strategies of speech acts, i.e., explicit and implicit speech acts, Table (4) below shows them with the frequency of their appearance in the data of the study.

As illustrated by Table (4), both explicit and implicit speech acts are used in the headlines of CCN and BBC news channels. Moreover, explicit speech acts have higher percetages in $\mathrm{CNN}$ than those in BBC news channels. They are singled out with a frequency of appearance that amounts to 18 and a percentage of $69.23 \%$ in CNN headlines whereas implicit speech acts are identified with a frequency of appearance that amounts to 20 and a percentage of $66.66 \%$ in $\mathrm{BBC}$ headlines.Implicit speech acts have a frequency of appearance in the headlines of $\mathrm{CNN}$ that amounts to 8 and a percentage of $30.76 \%$ while they are identified with a frequency of appearance that amounts to 10 and a percentage of $33.33 \%$ in BBC headlines. From the above mentioned data, it is quite clear that explicit and implicit speech acts are employed in the headlines of both channels.Moreover, explicit speech acts have higher percentages of employment than implicit speech acts. The percentages of using explicit speech acts and implicit speech acts in the headlines of CNN on the one hand and those of $\mathrm{BBC}$ on the other indicate no significant differences between the headlines of the two channels. This can be attributed to the fact that as the events are urgent in all the headlines, the writers of headlines try to convey the illocutionary force of these headlines depending on the saying verbs. This leads to employ explicit speech acts more.

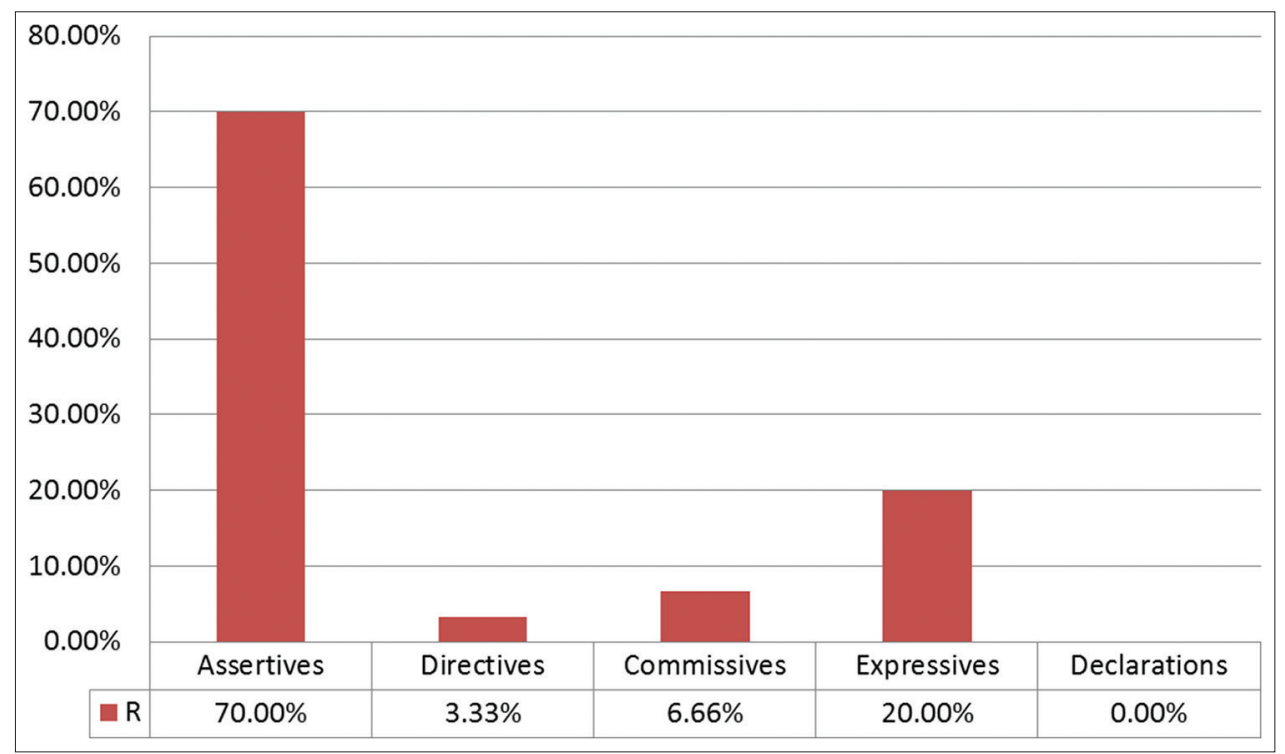

Figure 3. Percentages of the Speech Acts Used in Headlines on BBC News Channel

Table 3. The cumulative types of speech acts and their percentages of use in headlines on CNN and BBC news channels

\begin{tabular}{|c|c|c|c|c|c|c|c|c|c|c|c|c|}
\hline \multirow{2}{*}{$\begin{array}{l}\text { Speech acts } \\
\text { News channels }\end{array}$} & \multicolumn{2}{|c|}{ Assertives } & \multicolumn{2}{|c|}{ Directives } & \multicolumn{2}{|c|}{ Commissives } & \multicolumn{2}{|c|}{ Expressives } & \multicolumn{2}{|c|}{ Declarations } & \multicolumn{2}{|c|}{ Total } \\
\hline & No & $\%$ & No & $\%$ & No & $\%$ & No & $\%$ & No & $\%$ & No & $\%$ \\
\hline $\mathrm{CNN}$ & 18 & 69.23 & 1 & 3.84 & 4 & 15.38 & 2 & 7.69 & 1 & 3.84 & 26 & \\
\hline $\mathrm{BCC}$ & 21 & 70 & 1 & 3.33 & 2 & 6.66 & 6 & 20 & 0 & 0 & 30 & \\
\hline
\end{tabular}




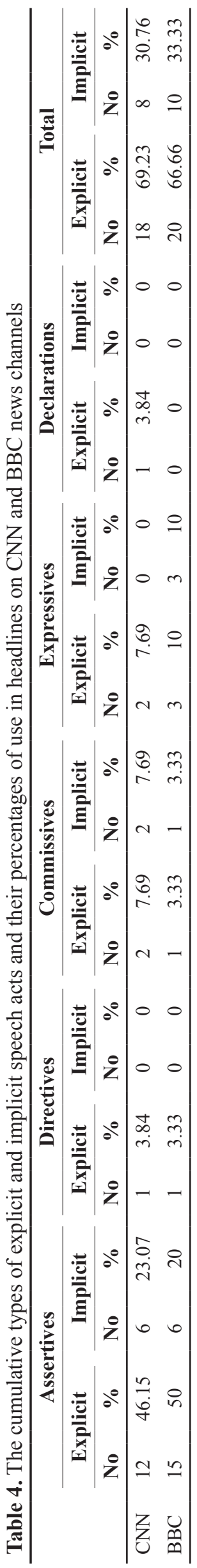

It is also noticed that implicit speech acts are less than explicit speech acts in the headlines of both news channels. This employment may be attributed to the fact that headlines reportes want to avoid direct reference to the propositions included in the headlines in order to capture the reader's attention.Figure (5) below also presents a breakdown of the speech acts employed.

According to the results above, it is found that $\mathrm{BBC}$ headlines do not employ all the five types classified by Searle (1979[1975]). With respect to these types, declarations are not used in the headlines of BBC. So, the first and the second research questions have been met. With the abundant use of assertive speech acts in the headlines of CNN and BBC news channels, the third question has been met. This can be attributed to the fact that assertives are used to give truthful information to the reader. Data analysis shows that explicit speech acts have higher percentages of employment than implicit speech acts in the headlines of the two channels. Consequently, the fourth question has been met.

The analysis of the data demonstrates that there are some similarities and differences in the two corpora obtained from the headlines of $\mathrm{CNN}$ and $\mathrm{BBC}$ channels. The headlines of the two channels are similar in that both channels show preference to assertive speech acts. The results also indicate that the headlines used by CNN news channel manifest a preponderance of commissive speech acts. BBC news channel headlines, on the other hand, are marked by the nonoccurrence of declarations. One reason is related to the nature of these headlines that reporters are not in a position to give orders or issue commands. Directive speech acts are higher in $\mathrm{BBC}$ headlines than they are in $\mathrm{CNN}$ headlines.

\section{CONCLUSIONS}

On the basis of the findings of the analysis arrived at in the previous section, the study has come up with the following conclusions:

1. Assertive speech acts outnumber the other speech acts which are employed in the headlines of both $\mathrm{CNN}$ and BBC news channels.

2. The two corpora obtained from the headlines of $\mathrm{CNN}$ and $\mathrm{BBC}$ channels covering the Syrian conflict show that they are similar in the following aspects:

a. Both channels have similar percentages of using assertives and declarations in their headlines.

b. The two channels employ explicit and implicit speech acts as strategies for realizing speech acts in the headlines. In this regard, explicit speech acts have higher percentages of employment than implicit speech acts.

3. Data of the study indicate certain differences between the headlines of the two channels as follows:

a. CNN headlines show a preponderant use of commissive speech acts whereas BBC headlines show an eminent employment of expressives.

b. CNN channel headlines are marked by a low rate of exploiting directives and declarations whereas BBC channel headlines show no use of declarations.

4. Although expressives in $\mathrm{CNN}$ headlines and directives and commissives in BBC headlines are exploited, their rates are still low. 


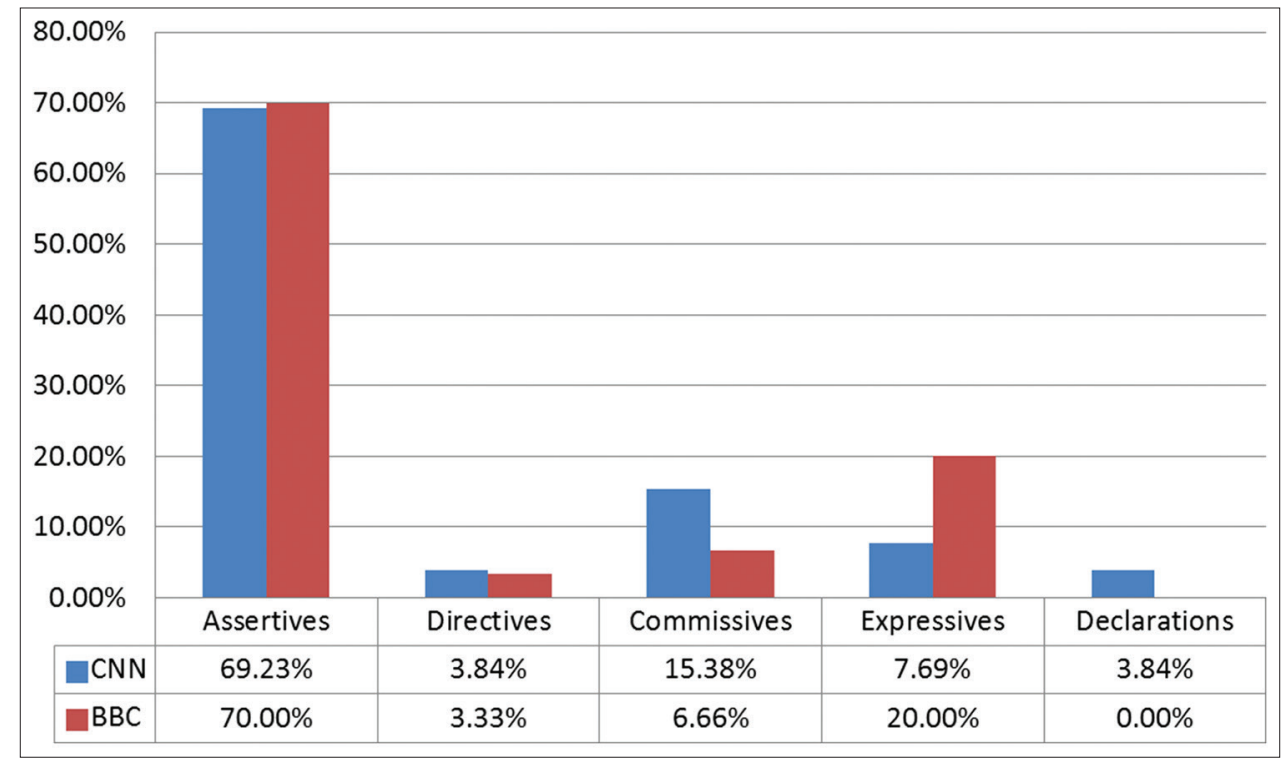

Figure 4. Percentages of the Speech Acts Employed in Headlines on CNN and BBC News Channels

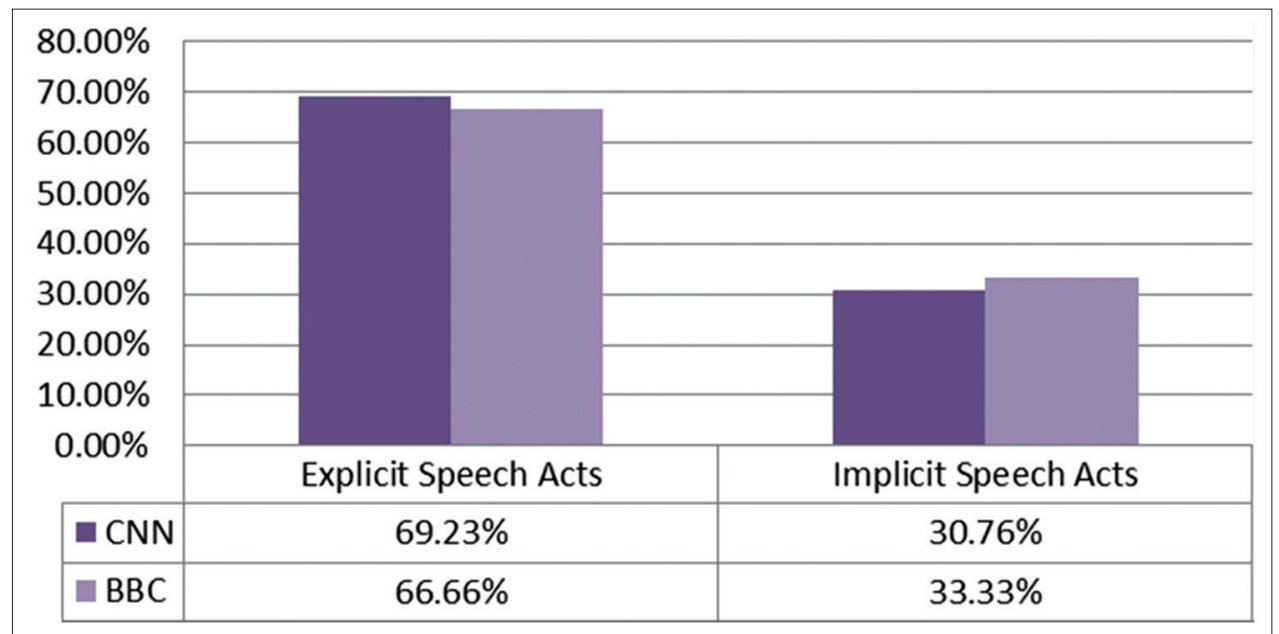

Figure 5. Percentages of Explicit and Implicit Speech Acts Employed in the Headlines on CNN and BBC News Channels

5. On the basis of the conclusions above, one can infer that the study of speech acts in headlines on news channels can be an instrumental way to reveal the intended meaning and thus, affect the readers' beliefs about certain issues.

\section{REFERENCES}

Abba T. S. and Nasiru, M. (2015). "Speech Act Analysis of Daily Trust and The Nation Newspapers Headline Reports on "Boko Haram" Attacks" Journal of Communication and Culture, 6(1), April, pp. 63-72.

Beard, A. (2000). The Language of Politics.London: Rutledge.

Bednarek,M., and Caple, H. (2012). News Discourse. London: Continuum.

Bell, A. (1991). The Language of News Media. Cambridge,MA: Blackwell.

Chiluwa, I. (2007) "News Headlines as Pragmatic Strategy in Nigerian Press Discourse." The International Journal of Language, Society and Culture, 27, 63-71.
Conboy,M. (2007) The Language of News. New York: Routledge.

Crystal, D. and Davy, D. (1969). Investigating English Style. London: Longman.

Dor, D. (2003) “On Newspaper Headlines as Relevance Optimizers.” Journal of Pragmatics,35, pp.695.-721.

Duanprakhon, P. (2012) "Critical Discourse Analysis of News Headlines: A Case of Youth Crime in Thailand.' Unpblished M. A. Thesis National Institute of Development Adminstration

Fowler, R. (1991) Language in the News: Discourse and Ideology in the press. London: Rutledge.

Mardh, I. (1980) Headlinese: On the Grammar of English Front Page Headlines. Malmö,Sweden: CWK Gleerup.

Mey, J. L. (2001) Pragmatics: An Introduction.Oxford: Blakwell Publisher.

Muhammed, M. M. (2005) “A Pragmatic Analysis of Selected English Political Newspaper Headlines.” Unpublished M.A. Thesis University of Baghdad, Iraq.

Prakash, A. and Dhawan, A. (2017). "Linguistic Divergences in Newspaper Headlines.” International Journal 
of Engineering Technology Science and Rresearch, 4(7), July.pp.858-864.

Reah, D.(1998). The Language of Newspaper. London: Rutledge.

Reah, D. (2002) The Language of Newspaper. $2^{\text {nd }}$ Edition London: Rutledge.

Roya, M and Mahadi, T. (2017). The Rhetoric of Persian News Headlines: A Case Study of Euronews. International Journal of Applied Linguistics and English Literature, 6(2), March,pp.36-45.

Rustam, R. (2013). Pragmatic Analysis of CNN Headlines Representing Pakistan. Unpublished Ph.D. Dissertation, University of Azad Jammu and Kashmir, Muzaffarabad, Pakistan.

Searle, J. R. (1969). Speech Acts: An Essay in the Philosophy of Language. Cambridge: Cambridge University Press.

Searle, J. R. (1979). "A Taxonomy of Illocutionary Acts", in Searle J. R. (ed.) Expression and Meaning: Studies in the Theory of Speech Acts, Cambridge: Cambridge University Press pp. 1-29 (originally published in 1975).

Siposova, A. (2011). Headlines and Subheadlines: Tense, Modality and Register Based on Discourse Analysis of The British Tobloid The Sun. Unpublished Ph.D. Dissertation, Masaryk University, Berno, Czech Republic.

Taiwo,R. (2007). "Language, Ideology and Power Relations in Nigerian Newspaper Headlines." Nebula,4(1). 218245.

Tuchman, G. (1978). Making News a Study of the Construction of Reality. NY: Free Press.

Ungerer, F. (ed.) (2000). English Media Texts Past and Present Language and Textual Structure Philadelphia, PA: John Benjamins.

Van Dijk,T A. (1977). Text and Context: Explorations in the Semantics and Pragmatics of Discourse. London; Longman.

\section{APPENDIX}

Appendix (A)

Headlines of CNN

\begin{tabular}{|c|c|c|}
\hline Headline no. & Headline & Speech act type \\
\hline 1 & Report: Russia releases plan to end Syrian civil war & Assertive \\
\hline 2 & Cruz: U.S. should stay out of Syrian civil war & Directive \\
\hline 3 & Aid workers in ISIS bull's-eye: 'If not us, then who?' & Assertive \\
\hline 4 & Aid groups say world is failing Syria's civilians & Expressive \\
\hline 5 & Syrian official: We're ready for 'real' talks & Commissive \\
\hline 6 & France, U.S. struggle Syrian refugee issue after attack in Paris & Assertive \\
\hline 7 & U.N. turns to crowdfunding app to feed Syrian refugees & Assertive \\
\hline 8 & Seeking shelter from Syria's civil war & Assertive \\
\hline 9 & Gordon Brown: 2015 a year of fear for refugee children & Assertive \\
\hline 10 & Canada: We'll resettle 25,000 Syrian refugees & Commissive \\
\hline 11 & Pentagon reviews troubled program to train Syrian rebels & Assertive \\
\hline 12 & Syria civil war prompts first 'Doomsday Vault' withdrawal & Assertive \\
\hline 13 & How is this not World War III? & Assertive \\
\hline 14 & Kerry, Lavrov meet to end impasse over Syria talks & Assertive \\
\hline 15 & Battle for Aleppo: Syrian civil war may get much worse & Assertive \\
\hline 16 & Obama announces extra 250 spec ops troops to Syria & Declaration \\
\hline 17 & Obama pledge to take 10,000 Syrian refugees behind schedule & Commissive \\
\hline 18 & Syria strike kills al-Nusra spokesman, SOHR says & Assertive \\
\hline 19 & Israel will never return Golan Heights, Benjamin Netanyahu says & Commissive \\
\hline 20 & Syria: ISIS takes hundreds at cement factory, report says & Assertive \\
\hline 21 & Rio 2016: Syrian refugee carries Olympic torch & Assertive \\
\hline 22 & Syria: ISIS dumped bodies in mass grave in Palmyra & Assertive \\
\hline 23 & ISIS claims it shot down Syrian regime jet near Damascus & Assertive \\
\hline 24 & Syrian war: General counts Russia as blessing in ISIS fight & Expressive \\
\hline 25 & Syria peace talks: Regime, opposition to try again & Assertive \\
\hline 26 & Aleppo siege: Syrian city on edge, trying to survive & Assertive \\
\hline
\end{tabular}




\section{Appendix (B)}

\section{Headlines of BBC}

\begin{tabular}{|c|c|c|}
\hline Headline no. & Headline & Speech act type \\
\hline 1 & Donald Trump: I would send Syrian refugees home & Commissive \\
\hline 2 & Iran quietly deepens involvement in Syria's war & Assertive \\
\hline 3 & Obama's struggle to realise anti-war rhetoric & Assertive \\
\hline 4 & 100 Women 2015 Good Girls/Syria: 'Everyone has deserted us' & Expressive \\
\hline 5 & Migrant crisis: We need to 'smash' trafficking gangs-PM & Expressive \\
\hline 6 & Syria conflict: Nato warns Russia on air strikes & Assertive \\
\hline 7 & Syria conflict: Attacks reported as truce comes into effect & Assertive \\
\hline 8 & Russia’s Syrian bombing gives boost to Iran & Assertive \\
\hline 9 & Syrian President Bashar al-Assad: Facing down rebellion & Assertive \\
\hline 10 & Syria civil war: Army 'steps up offensive from Palmyra' & Assertive \\
\hline 11 & Syria civil war: Assad hails Palmyra recapture from IS & Expressive \\
\hline 12 & Syria civil war: Donors pledge billions in vital aid & Assertive \\
\hline 13 & Madaya: 'Horrifying conditions' in besieged Syrian town & Assertive \\
\hline 14 & Syrian refugee numbers soar at Turkey border6 & Assertive \\
\hline 15 & EU calls on Turkey to let Syrian refugees cross border & Assertive \\
\hline 16 & Madaya: 'Another 16 starve to death' in besieged Syrian town & Assertive \\
\hline 17 & Syria war: Thousands fleeing fighting mass at Turkey border & Assertive \\
\hline 18 & Syria refugee camps set up as Turkey limits entries & Assertive \\
\hline 19 & Madaya Syria: '400 residents must leave' for medical treatment & Assertive \\
\hline 20 & Syria crisis: UK should take in 3,000 children, say MPs & Directive \\
\hline 21 & Syria conflict: UN fears Aleppo assault could cut off 300,000 civilians & Expressive \\
\hline 22 & Syrians spending first Christmas in UK & Commissive \\
\hline 23 & Syria : Kerry tries to salvage 'out of control civil war' & Assertive \\
\hline 24 & Syrian refugees: Families arriving in Belfast 'grateful' to be safe & Expressive \\
\hline 25 & Syria conflict: Air strike on refugee camp 'could be war crime' & Assertive \\
\hline 26 & Syria conflict: Assad strategy won’t end Syria war, says Kerry & Assertive \\
\hline 27 & MSPs voice support for Syrian civil war victims & Assertive \\
\hline 28 & Syria conflict: Civilians under siege & Assertive \\
\hline 29 & Syria: Many countries ‘have not done enough' says Solberg & Expressive \\
\hline 30 & Oxfam urges rich nations to take in more Syria refugees & Assertive \\
\hline
\end{tabular}

